Arthington Angela H., Robert J. Naiman, Michael E. McClain and Christer Nilsson (2010). Preserving the biodiversity and ecological services of rivers: new challenges and research opportunities. Freshwater Biology 55 (1): 1-16, Special Issue on Environmental Flows; Science and Management.

\title{
Preserving the biodiversity and ecological services of rivers: new challenges and research opportunities
}

Angela H. Arthington ${ }^{1}$, Robert J. Naiman ${ }^{2}$, Michael E. McClain ${ }^{3}$ and Christer Nilsson ${ }^{4}$

1 a.arthington@griffith.edu.au

Australian Rivers Institute and eWater Co-operative Research Centre, Griffith University, Brisbane, Queensland 4111, Australia

${ }^{2}$ School of Aquatic \& Fishery Sciences, University of Washington-355020, Seattle, WA 98195 USA

${ }^{3}$ UNESCO-IHE Institute for Water Education, Delft, The Netherlands and Department of Earth and Environment, Florida International University, Miami, FL 33199 USA

${ }^{4}$ Landscape Ecology Group, Department of Ecology and Environmental Science, Umeå University, SE-901 87 Umeå, Sweden

\section{Summary}

1. Natural biogeochemical processes and diverse communities of aquatic biota regulate freshwater quantity and quality in ways that are not sufficiently acknowledged nor appreciated by the water resources management community. The establishment and enforcement of environmental flow requirements offer a promising means to improve and care for these critical environmental services. This Special Issue provides new insights and novel techniques to determine, protect and restore ecologically and socially sustainable flow regimes, and thereby help achieve the water-related goals of the Millennium Ecosystem Assessment.

2. While alteration of flow, sediment, organic matter and thermal regimes interact to reduce biological diversity and the ecological integrity of freshwater ecosystems - and 
thereby degrade the properties and ecological services most valued by humans 'environmental flows' left in rivers, or restored to developed rivers, will sustain many ecological and societal values. The success of river protection and rehabilitation/restoration depends upon understanding and accurately modelling relationships between hydrological patterns, fluvial disturbance and ecological responses in rivers and floodplains.

3. This Special Issue presents new analytical and modelling approaches to support the development of hydro-ecological models and environmental flow standards at multiple spatial scales - applicable to all rivers in any economic and societal setting. Examples include the new framework ELOHA (Ecological Limits of Hydrologic Alteration) founded on hydrological classification and gradient analysis, ecological trait analysis, Bayesian hierarchical modelling, Bayesian Decision Networks (BDNs) and Integrated Basin Flow Assessment (IBFA).

4. Advances in the allocation of flood flows along the River Murray in Australia, an Ecosystems Function Model (HEC-EFM) for the Bill Williams River restoration programme in Arizona (USA), the European Water Framework Directive, and improved management of hydroelectric dams demonstrate the potential for significant ecological recovery following partial restoration of natural river flow regimes.

5. Based on contributions to this Special Issue, the action agenda of the 2007 Brisbane Declaration on environmental flows and the wider literature, we propose an invigorated global research programme to construct and calibrate hydro-ecological models and to quantify the ecological goods and services provided by rivers in contrasting hydro-climatic settings across the globe. A major challenge will be to find acceptable ways to manage rivers for multiple uses. Climate change intensifies the urgency. Environmental flows help to preserve the innate resilience of aquatic ecosystems, and thereby offer the promise of improved sustainability and wellbeing for people as well as for ecosystems.

Keywords: rivers, biodiversity, ecological services, environmental flows, river restoration 


\section{Introduction}

Fresh waters in lakes, wetlands and rivers support ecosystems with diverse life forms that, together with the water itself, provide goods and services of critical importance to human societies everywhere (Postel \& Carpenter, 1997; Millennium Ecosystem Assessment, 2005). A daily supply of clean fresh water is essential to every human. In developed countries freshwater ecosystems are the source of water subsequently treated and distributed to users. Conversely, hundreds of millions of people in the developing world continue to collect drinking and domestic water directly from aquatic ecosystems and treat at the point of use. An alarming number of people still consume polluted and contaminated water with no form of treatment. The biogeochemical processes and diverse aquatic species that regulate freshwater quantity and quality are not sufficiently acknowledged nor appreciated, as exemplified by pervasive degradation of the world's freshwater resources (Nilsson et al., 2005; Tockner et al., 2008). Furthermore, freshwater ecosystems underpin global food production based upon artisanal and commercial fisheries, aquaculture, floodplain regression agriculture and pastoral animal husbandry (Postel, 2005; Welcomme et al., 2006a; Sala et al. 2008). The fibres and biochemicals derived from riparian and wetland plants are critically important to human welfare and livelihoods in many parts of the world, as are other regulating and cultural services (Millennium Ecosystem Assessment, 2005). These ecological goods and services are increasingly threatened by human activities in rivers and their catchments.

There are five principal categories of threat to fresh waters - overexploitation, water pollution, fragmentation, destruction or degradation of habitat, and invasion by nonnative species (Malmqvist \& Rundle, 2002; Dudgeon et al., 2006); all are linked and exacerbated by the modification of river flows and wetland inundation regimes. Land use change, river impoundment, surface and groundwater abstraction and artificial inter/intra- 
basin transfers profoundly alter natural flow regimes (Poff et al., 1997; Naiman et al., 2002; Postel \& Richter, 2003; Revenga et al., 2005; Pearce, 2007). Globally, the modification of river flows is so pervasive that the $\sim 45,000$ dams above $15 \mathrm{~m}$ high are capable of holding back $>6500 \mathrm{~km}^{3}$ of water, or about $15 \%$ of the total annual river runoff globally (Nilsson et al., 2005). The area of formerly terrestrial habitat inundated by large reservoirs is comparable with the area of California or France (Dynesius \& Nilsson, 1994). In addition, increasing numbers of rivers are so deprived of water that they no longer reach the ocean, permanently or for parts of the year (Postel \& Richter, 2003; Pearce, 2007). These fundamental alterations to the freshwater portion of the Earth's hydrological system are increasing in many regions: human population growth, industrial development, water scarcity, and alterations to rainfall/runoff patterns associated with climate change are the main drivers. Current water management practices may no longer be appropriate for the unpredictable flow regimes of a warmer and more densely populated world (Vörösmarty et al., 2004; Alcamo et al., 2008; Milly et al., 2008; Palmer et al., 2008).

Human needs for fresh water and dependence upon the ecological goods and services supported by healthy freshwater ecosystems present a major challenge for water managers and scientists alike. Scientists need to develop tools and models to inform and facilitate ecologically sustainable water management, thereby balancing human and ecological demands for fresh water in complex, dynamic and changing social and political environments.

One of the most promising strategies for integrating freshwater management into the broader scope of ecological sustainability is the provision of 'environmental flows' - the flows left in rivers, or restored to developed rivers, to sustain select [or key] ecological and societal values. Other terms such as 'in-stream flows', 'ecological flows', 'environmental water allocations', and the 'normative flow regime' convey much the same concept. However, 'environmental flows' is now so well-entrenched (Dyson, Bergkamp \& Scanlon, 2003; Tharme, 2003; Acreman \& Dunbar, 2004; Hirji \& Davis, 2009) and widely applied that we promote the term and definition endorsed by delegates 
attending the International Environmental Flows Conference held in Brisbane, Australia, in September 2007:

"Environmental flows describe the quantity, timing and quality of water flows required to sustain freshwater and estuarine ecosystems and the human livelihoods and well-being that depend upon these ecosystems" (Brisbane Declaration, 2007, Appendix 1)

This definition signals important aspects of environmental flow management that warrant more attention and wider observance. First, the 'quality' of water (i.e., its chemical and thermal properties) is as important as the quantity and temporal patterns of flow (Nilsson \& Renöfält, 2008; Olden \& Naiman, this volume). The Declaration also highlights the continuity of rivers and estuaries and their mutual dependence on freshwater flows, and makes an explicit link between environmental flows, river and estuarine ecosystems and the livelihoods and well-being of societies dependent upon them. Many freshwater systems (groundwater, wetlands, and lakes) depend largely upon a standing water regime rather than flowing water; however, the scientific development of environmental flow concepts and methods has centred on the water requirements of rivers, and they are the focus of this Special Issue.

Two international conferences held in south-eastern Queensland, Australia, in the spring of 2007 - the Brisbane International Environmental Flows Conference and the Third International Symposium on Riverine Landscapes (TISORL) - provided rich and timely resources for this Special Issue devoted to the science and management of environmental flows. We sought additional contributions to broaden the scope and geographic coverage of papers.

There is now wide recognition that a dynamic, variable water regime is required to maintain the native biodiversity and ecological processes characteristic of every river and wetland ecosystem (Poff et al., 1997; Postel \& Richter, 2003; Lytle \& Poff, 2004). Yet it remains a challenge to translate this 'natural flow regime' paradigm into quantitative environmental flow prescriptions for individual river reaches from source to sea 
(Arthington et al., 2006; Bernhardt et al., 2006). Hydro-ecological principles capture and illustrate the myriad ecological roles of flow magnitude, flood frequency, timing and duration, and other dimensions of flow history and recent flow events (Junk, Bayley \& Sparks, 1989; Poff et al., 1997; Richter et al., 1997; Bunn \& Arthington, 2002; Naiman et al., 2002; Nilsson \& Svedmark, 2002; Pinay et al., 2002; Lytle \& Poff, 2004). However, paradigms and principles must be supported by practical tools, methods, protocols and models accurately linking volumes and patterns of flow to biodiversity and ecological processes. The task is made more difficult by the inherent variability of river flows and poor understanding of how far they can be altered beyond the natural range before unacceptable ecological change becomes apparent (Gladwell, 2000; Merrett, 2007). At least 200 environmental flow methods and approaches are in use, each aiming to quantify the water requirements of species, communities, or rivers as ecosystems (Dyson et al., 2003; Tharme, 2003; Arthington et al., 2004; Richter et al., 2006). Yet there still remains a critical need for greater understanding of flow-ecological response relationships and enhanced modelling capacity to support river flow management and ecosystem conservation.

The papers in this Special Issue address two main contexts that require assessment of environmental flows - river rehabilitation/restoration and river protection. First, an appreciation of the ecological damage caused by past flow regulation has led to major river rehabilitation and partial restoration efforts involving the provision of environmental flows, often linked to other strategies such as fish passage facilities, improved habitat and riparian replanting (Stanford et al., 1996; Bernhardt et al., 2005; Palmer et al., 2005; Jansson, Nilsson \& Malmqvist, 2007). The flow-related objective is to restore specific aspects of the biodiversity, ecological processes and services of stressed rivers by restoring some of the defining characteristics of the original natural flow regime (Poff et al., 2003; Richter \& Thomas, 2007). Second, river protection involves a more proactive approach to define and quantify flow volumes and temporal patterns that sustain particular ecological and societal values. Proactive methods come into play at the planning stage of new infrastructure developments, and in catchmentscale water resource assessment and planning (Arthington \& Pusey, 2003; King \& 
Brown, 2006). In both circumstances the crucial requirement is to accurately predict the ecological outcomes and derived social/economic benefits likely to result from environmental flow provisions, and to do so in a timely and efficient manner without depending on lengthy research projects for answers.

This Special Issue addresses both of these contexts, and is accordingly wide-ranging. Although not comprehensive relative to the full breadth and vigour of the field, it includes synoptic reviews, methodological innovations, environmental flow experiments, modelling techniques and broader principles to support the sustainable use of the freshwater resources of river basins. We hope that increasing capacity to provide quantitative environmental flow prescriptions will enable river restoration and protection to progress more effectively, widely and rapidly than at present. To aid in this process, in the following sections, we draw out the main findings for river restoration and protection, and identify new challenges and research opportunities linked to implementation and capacity-building. We propose an invigorated global research programme on hydroecological relationships and thresholds of ecological response, to support the implementation of environmental flows in all threatened and impacted rivers, and thereby help achieve the water-related goals of the Millennium Ecosystem Assessment.

\section{River restoration}

In developed areas of the world, many of the goods and services originally provided by river ecosystems have been lost or diminished because of excessive water use and alterations to flow regimes. Here the greatest need - in addition to political will - is for methods and models to aid the restoration of a more natural flow regime (Arthington $\&$ Pusey, 2003; Poff et al., 2003; Jansson et al., 2007; Lake et al., 2007). In Australia, a major river restoration programme ('The Living Murray' initiative) established in 2004 aims to return the highly regulated River Murray to the status of a "healthy working river" (COAG, 2004: URL: www.thelivingmurray.mdbc.gov.au). It proposes to do this by recovering a long-term average of up to $500 \mathrm{GL}\left(500,000,000 \mathrm{~m}^{3}\right)$ per year of water over a 5-year period. This environmental water is expected to achieve defined ecological 
objectives at six iconic wetland sites along the river and in the channel itself. Hydrological and ecological modelling, empirical research and experimental flow releases are informing decisions about the volumes, timing, frequency and quality of water required to restore wetland values. A. King and her colleagues (this volume) describe the positive outcomes for native fish recruitment following delivery of the largest environmental flow in Australia's history (513 GL) to River Redgum (Eucalyptus camaldulensis) forests at Barmah-Millewa on the River Murray. This Ramsar wetland supports native fishes, frogs and waterbirds protected under the Japan-Australia Migratory Bird Agreement (JAMBA) and China-Australia Migratory Bird Agreement (CAMBA). The positive lessons and precautionary tales from the work of King and colleagues will undoubtedly inform the management of other Murray-Darling wetlands destined to receive environmental water under the new Environmental Watering Plan for the Murray-Darling Basin, due in 2011 (URL: http://www.environment.gov.au/water/policy-programs/cewh/index.html).

As another example of restoration, the 'Water Framework' Directive (WFD) of the European Union (EU), is a ground-breaking policy integrating water management and ecosystem conservation, aiming to achieve 'Good Ecological Status' (GES, referenced to aquatic biology) in most European rivers, lakes and wetlands by 2015 (European Commission, 2000). In the United Kingdom (UK), the implementation of environmental flows is one of the measures being applied to restore or to maintain river ecosystem health. Whilst a consistently applied environmental flow methodology (e.g., some form of 'functional' or 'building block' approach, see Dyson et al., 2003) is a goal, none has yet emerged from the efforts of the EU member states. M. Acreman and A. Ferguson (this volume) describe the challenges presented by the WFD and the difficulties arising from the requirement to define environmental flows across such a wide geographic realm. Two practical approaches address the provision of environmental flows: the use of set water abstraction limits that maintain a healthy river ecosystem (termed 'restrictive management') and the definition of ecologically appropriate flow releases from reservoirs. 
In many European and other countries particular water management challenges arise in rivers affected by hydropower plants. This is because the dams and diversions necessary for electricity production fundamentally transform rivers and their ecosystems, leaving little latitude for flow regime adjustments to benefit aquatic ecosystems (Renöfält, Jansson \& Nilsson, this volume). An important challenge in these regulated rivers is to identify situations where measures imposing relatively small losses in power production can have significant positive ecological effects. In northern and central Sweden, climate change during the $21^{\text {st }}$ century is expected to increase annual runoff and modify the annual hydrograph so that it is more aligned with patterns of variation in electricity demand (i.e., a lower spring flood and increased run-off during winter months). B. Renöfält and her colleagues suggest that climate-induced change in hydrographs could provide more opportunities for operating dams and power stations to the greater benefit of riverine ecosystems.

In restoration studies, it is common practice for several scenarios of reservoir management to be explored and modelled, and to support this approach the range of models as well as their capabilities have diversified remarkably since the first hydraulic habitat methods (e.g., PHABSIM and related software programs; Bovee et al., 1998; Gippel \& Stewardson, 1998; Tharme, 2003). An informative case example of model development and application can be seen in the environmental flow restoration programme on the Bill Williams River (BWR), an arid-region river in Arizona, western USA (P. Shafroth and his colleagues). Here simulation modelling of reservoir operations, surface and groundwater interactions and river hydraulics are linked to an Ecosystems Function Model (HEC-EFM) that predicts spatially explicit patterns of riparian seedling recruitment, the dynamics of different benthic macroinvertebrate functional feeding groups, as well as beaver dam integrity and distribution in response to various alternatives for dam operation and water releases. Experimental flow releases and empirical studies in the BWR allow for calibration of ecosystem models and response thresholds, with outcomes informing alternative reservoir operational rules, cast within an adaptive management framework. 
A guiding principle of environmental flows is that the water regime is the "master variable' (Power et al., 1995; Walker, Sheldon \& Puckridge, 1995) driving the diversity and vitality of river and floodplain ecosystems. Yet we know that the flow regime is not the only driver of riverine ecosystem structure and function, nor the only aspect of environmental flows that needs to be considered. Temperature also plays an important role, working through a different but vital pathway - the metabolism of organisms. J. Olden and R. Naiman (this volume) call for a clearer elucidation of the relative roles of altered flow and temperature in shaping ecological patterns and processes in riverine ecosystems. Many human activities in the landscape have modified riverine thermal regimes, and dams in particular generate modified thermal regimes by selectively releasing hypolimnetic (cold) or epilimnetic (warm) water from thermally stratified reservoirs, to the detriment of entire assemblages of native organisms. This paper explores the concept of the natural 'thermal regime', and identifies five major challenges for incorporating water temperature into environmental flow assessments. These include identifying the "manageable" components of the thermal regime and developing optimization models that evaluate management trade-offs, to provide a range of optimal environmental flows that meet both ecosystem and human needs for fresh water.

River restoration/rehabilitation by flow regime manipulation is frequently said to offer ideal opportunities for conducting large-scale, hypothesis-driven ecosystem experiments within a framework of adaptive environmental management (Biggs \& Rogers, 2003; Poff et al., 2003; Schreiber et al., 2004; King et al., this volume). A BACI (Before-After Control-Impact) or related design is generally the best way of detecting impacts or beneficial outcomes in river systems (Downes et al., 2002); however such designs are rarely possible for assessing the effects of environmental flows in degraded systems that have no parallels as baseline or 'reference' conditions (Stoddard et al., 2006; Nilsson et al., 2007). Furthermore, the provision of environmental flows is typically a patchy (even ad hoc) phenomenon, both in space and time, and it is often difficult or impossible to identify the point in time separating 'before' from 'after' an environmental flow. Moreover, the level of flow enhancement is likely to be continuous, rather than categorical, and natural processes may also deliver flow along the experimental channel. 
In addition, finding sufficient replicates to achieve a high level of statistical power is rarely feasible, and ensuring their independence in a dendritic, interconnected river system adds another level of difficulty. These problems can be complicated by other disturbances with singular and interactive effects that cannot be factored out of the flow experiment's design (Downes et al., 2002).

As an alternative, A. Webb and his colleagues (this volume) explore the utility of a Bayesian hierarchical approach to improve detection of important associations between stream flows, including managed environmental flows, and biophysical responses in rivers. Properties unique to the hierarchical approach - "borrowing strength" and "shrinkage" - mean that conclusions can be greatly strengthened in data-poor situations but will be almost unaffected when data are plentiful. Webb and his colleagues stress that the flexibility of Bayesian modelling allows formulation of realistic models, which can be tested for generality using all available data from any source (e.g., routine river health monitoring data, or a particular flow experiment). Models can be updated as new knowledge and data become available via an iterative cycle of development and testing. The advantages appear obvious given that environmental flow monitoring programmes often require a large investment of public money. Management agencies need to be convinced their investments in environmental flows and the monitoring of ecological outcomes are cost-effective and worthwhile activities.

\section{River protection}

Developing countries typically need to use their water resources for traditional societal benefits and economic gain yet face immense international pressure (e.g. the World Commission on Dams, 2000; DIVERSITAS - Naiman et al., 2006; Brisbane Declaration, 2007) to consider the full suite of environmental and social costs before water use decisions are made (King \& Brown, 2006). Such considerations require a methodology to generate a range of environmental flow scenarios, each one representing the quantities and timing of water flows that could be maintained within the river system at appropriate times of year and with regionally appropriate annual/inter-annual frequencies (Arthington 
\& Pusey, 2003; King, Brown \& Sabet, 2003). Equipped with a range of scenarios it is then possible to explore tradeoffs between the ecological values protected and the loss of revenue that could be derived from water use off-stream or in hydropower generation, for example.

Detailed habitat simulation studies using PHABSIM (Bovee et al., 1998) have been regarded as inappropriate for use in countries with limited resources and where environmental flow assessments are needed in thousands of rivers proposed for future water resource developments. Furthermore, a focus on habitat requirements and the provision of a 'minimum' flow to provide fish habitat, are nowadays considered to be inadequate for protecting biodiversity and ecosystem services (Arthington et al., 2004; Renöfält et al., this volume). The 1990s saw the emergence of 'holistic' methods that address a wider range of hydro-ecological relationships along the full continuum of the 'riverine' ecosystem. These ecosystem approaches employ panels of river scientists, managers and citizens who bring their collective knowledge of rivers into an agreed decision support framework. Then, from this shared knowledge, the panel explores and recommends environmental flow requirements using the best available data, models and expert opinion (Cottingham et al., 2002; Dyson et al., 2003; Tharme, 2003; Arthington et al., 2006; King \& Brown, 2006; Richter et al., 2006).

J. King and C. Brown (this volume) trace these developments through case studies in Africa and south-east Asia, where much of the foundational work has been done. Their article highlights the realization that environmental flows must be embedded within a more expansive concept to achieve ecologically sustainable development of freshwater resources at the river basin scale. They describe the progressive development of what they term 'Integrated Basin Flow Assessment' (IBFA), which can illustrate, for any future development option, potential changes in a wide range of river characteristics, such as "channel configuration; bank erosion; water chemistry; riparian forests; river, estuarine and near-coastal marine fisheries; rare species; pest species; river-related human and livestock health; availability of baptism areas; household incomes; GDP; job creation; HEP production and much more". From the case studies described, King and Brown 
propose 10 principles to guide the merger of environmental flow assessment with integrated basin management in developing countries.

Scenario-based ecosystem methods were originally developed and are generally applied river-by-river. These approaches draw strength from knowledge of the subject river system or rivers of similar character, or the life history characteristics for species in nearby parts of their natural range (Arthington et al., 2003; Tharme, 2003; King \& Brown, 2006). Nevertheless, river managers often argue that river-by-river assessments are too slow and costly; they would like the ability to apply flow-ecology models and management 'rules' to many rivers and across wider biogeographic regions.

L. Poff and his colleagues (this volume) describe a new framework termed 'ELOHA' (Ecological Limits of Hydrologic Alteration), which addresses this expectation. They begin by noting that flow-ecological relationships and models are not necessarily exclusive to single rivers, but may be expected to apply to rivers of a particular hydrological type, such as arid-zone or snow-melt rivers with naturally distinctive flow regimes (Poff \& Allan, 1995). They suggest that rivers of similar hydrological character respond to a particular type of flow regime change in a similar fashion. If flow alterationecological response relationships hold true for each member of a distinctive hydrological class and each type of flow alteration, then environmental flow 'guidelines' or 'rules' could be developed and applied to all rivers of that class, thereby avoiding the need to develop such relationships and standards for each individual river within the class. ELOHA draws upon many well-accepted environmental flow methods and approaches that aim to make best use of available scientific knowledge, and to ascribe certainty levels to flow-ecological response relationships (see ELOHA Fact Sheet: URL: http://nature.vitamininc.net/water/pdfs/environmentalflows/Ecological_limits_ENGLISH.pdf ).

A first step in ELOHA and other environmental flow approaches is to develop a 'hydrological foundation' built upon natural and altered flow data, followed by hydrological classification and then identification of flow regime types or classes within a 
defined region of interest (e.g., a country, bioregion or large river basin). M. Kennard and his colleagues (this volume) illustrate essential principles and methods applied in the first continental-scale classification of unaltered hydrologic regimes for Australia. Their analyses are based on 120 metrics describing ecologically relevant characteristics of the natural hydrologic regime derived from 15-30 years of discharge data for 830 stream gauges. Classification using a fuzzy partitional method (i.e., Bayesian mixture modelling) revealed 12 classes of distinctive flow regime types differing in their seasonal flow pattern, degree of flow permanence (i.e., perennial versus varying degrees of intermittency), variations in flood magnitude and frequency, and other aspects of flow predictability and variability. Further, Kennard and his colleagues developed decision trees to establish natural flow regime classes based on key climatic and catchment topographic factors - necessary when flow data are lacking for some streams in a region. This national classification is already supporting environmental flow assessments for riverine restoration and preservation in Australian rivers threatened by development, drought and climate change.

Environmental flow assessments build upon knowledge of quantitative relationships among various types and degrees of flow alteration and associated ecological responses. The strengths of the knowledge base are explored by L. Poff and J. Zimmerman (this volume), who review 165 journal papers, with a focus on those recently published. They searched for general relationships that could be drawn from disparate case studies that might be used to inform environmental flows science and management. A "qualitative" or narrative summary of the reported results strongly corroborated previous, less comprehensive, reviews by documenting 152 (92\%) instances of decreased values for ecological metrics in response to a variety of flow alterations, whereas the remainder reported increased values. Even so, robust statistical relationships were not supported by these published studies of flow regime change in a wide range of rivers. Poff and his colleagues suggest that investigative programmes are needed across well-defined gradients of flow regime alteration to quantify ecological responses and develop robust, general flow alteration-ecological response relationships. Similarly, the collection of pre- 
and post-alteration data for new water development programmes would significantly add to a basic understanding of ecological responses to flow alteration.

The concept of generic flow-ecology relationships and models that could facilitate the transfer of flow-ecology knowledge from one river to another may underpin effective environmental flow strategies. D. Merritt and his colleagues (this volume) propose to organize riparian plants into non-phylogenetic groupings of species with shared traits that are related to components of hydrologic regime: life history, reproductive strategy, morphology, adaptations to fluvial disturbance, and adaptations to water availability. Plants from any river or region may be grouped into life history guilds and related to hydrologic attributes of a specific class of river using probabilistic response curves. Merritt and colleagues recommend that plant species response surfaces be fitted to environmental predictors that represent (1) limiting or regulating factors (those that control ecophysiology), (2) disturbances (perturbations that remove or redistribute biomass), and (3) resources (compounds that can be assimilated by organisms). They propose that riparian response guilds can be decomposed to the species level for individual projects or used to develop flow management guidelines for regional water management plans.

The idea of riparian flow-response guilds has parallels in recent work on fish guilds for conservation and management (Welcomme et al., 2006b) and studies of invertebrate functional trait niches (Poff et al., 2006). M. Dunbar and his colleagues (this volume) explore the utility of LIFE (Lotic Invertebrate index for Flow Evaluation) scores that index the preferences of stream invertebrate taxa for higher velocities and clean gravel/cobble substrates or slow velocities and silty substrates. Using time series of river biomonitoring data from wadeable lowland streams in England and Denmark, Dunbar and colleagues show how local-scale habitat features mediate the response of this macroinvertebrate community index to changing river discharge. Their study is particularly interesting because it also examines how habitat modification can affect invertebrate communities in streams, thereby potentially extending the idea of flow response guilds to habitat response guilds. The authors suggest that their approach may 
have broad applicability as a means for developing regional flow-ecological response models in natural and engineered stream channels.

The provision of environmental flows and the removal of barriers to water flow and fish migration are universally regarded as high priorities for restoration of impounded rivers (Stanford et al., 1996; Welcomme et al., 2006a; Palmer et al., 2005, 2008). Yet regulation of flow regimes is often accompanied by changes in catchment and riparian land use, and these disturbances also have major impacts on river ecosystem integrity, through water quality impacts, local habitat degradation, or modification of stream energy regimes (Bunn, Davies \& Mosisch, 1999; Pusey \& Arthington, 2003; Allan, 2004; Kennard et al., 2007). Although the potential for interactions among ecosystem stressors is often acknowledged (e.g., Baron et al., 2002; Bunn \& Arthington, 2002; Allan, 2004; Dudgeon et al., 2006; Poff et al., this volume), it is not uncommon for flow, catchment and riparian restoration objectives to be addressed in isolation rather than integrated into broader strategies directed toward ecological sustainability at the basin scale. If integrated catchment management is to become common practice, and be effective, how can river managers assess which flow and catchment interventions are most likely to succeed, where to locate them and, importantly, which are likely to be most costeffective?

B. Stewart-Koster and his colleagues (this volume) demonstrate the use of Bayesian Networks (BNs) to model relationships between flow and other environmental drivers of stream ecosystem health and ecological response variables. They then show how BNs can be modified to provide Bayesian Decision Networks (BDNs) that incorporate the relative costs and benefits of potential management actions. The inclusion of BDNs within existing frameworks for the assessment of environmental flows for river restoration would enhance capacity to evaluate the influence of multiple stressors on aquatic ecosystems, and the relative benefits of various restoration options.

Environmental flow provisions are not necessarily the most effective restoration solution, or may even be relatively ineffective when provided in the absence of pollution abatement, riparian management and habitat restoration. 


\section{New challenges and research opportunities}

In 2008, the Global Water System Project (GWSP) articulated a grand challenge for freshwater research - understanding how universal hydrologic changes in the freshwater system are increasing the vulnerability of ecosystems and society at global scale (Alcamo et al., 2008). In the GWSP prospectus, environmental flows are a central tool helping countries to protect freshwater biodiversity, resiliency and the ecological goods and services provided by healthy aquatic ecosystems. Likewise, freshwater issues are embedded in nearly all of the Millennium Development Goals, and good water stewardship, involving strategies such as environmental flows, will be fundamental to their success (Alcamo et al., 2008; Naiman \& Dudgeon, in press). Other prominent international programmes with a strong focus on resolving water conflicts have also embraced the concept of environmental flows (e.g., UNESCO-IHP, the IUCN, the DIVERSITAS freshwaterBIODIVERSITY Network, Conservation International (CI), the World Wide Fund for Nature (WWF), the Ramsar Convention, and the European Water Framework Directive). In addition, environmental flows are being assessed and implemented in many countries through international river basin partnerships and implementation projects. Examples include the Freshwater Sustainability Project of The Nature Conservancy (TNC), the work of the International Water Management Institute (IWMI, 2006), the World Bank (Hirji \& Davis, 2009), the Swedish Water House, the USAID Global Water for Sustainability Program (GLOWS), and the Brisbane International Riverfoundation. Three recent international conferences (Cape Town in 2002, Brisbane in 2007 and Port Elizabeth in 2009) have also given prominence to the science and implementation of environmental flows - always a lively theme during World Water Forums and Stockholm's World Water Weeks.

A document of particular relevance is the 2007 Brisbane Declaration, prepared on behalf of over 750 delegates at the $10^{\text {th }}$ International Riversymposium and Environmental Flows Conference (Appendix 1). The Declaration highlights the significance of environmental flow allocations for humans and nature, and sets out a global action agenda. This calls 
upon all governments, development banks, donors, river basin organizations, water and energy associations, multilateral and bilateral institutions, community-based organizations, research institutions, and the private sector across the globe to commit to actions for restoring and maintaining environmental flows in all rivers. We strongly endorse the Declaration's nine-point action agenda and in support, propose an invigorated, international research effort to strengthen the research component of environmental flow assessment and implementation in a variety of rivers. The methods and models discussed in this Special Issue have potential to greatly accelerate environmental flow assessments over far greater spatial scales than are typically attempted. A well-designed, supported and co-ordinated international research effort could meet the GWSP challenge to understand ecosystem water requirements at global scale, and identify those areas most needing protection or restoration (Alcamo et al., 2008). Further, a global environmental flows research programme built around local and regional river restoration/protection would assist in predicting ecological responses to scenarios of climate change, and to future human adaptive manipulation of water systems. Above all, we wish to promote linkages with the GWSP prospectus set out by Alcamo et al. (2008) and foster firm scientific foundations for achieving the water-related Millennium Development Goals.

From the contributions to this Special Issue, the action agenda of the Brisbane Declaration and the wider literature, we draw out the following themes that could form part of an enhanced global programme of environmental flows research, implementation and capacity building to support river conservation and restoration/rehabilitation.

(1) Hydro-ecological relationships. Environmental flow assessments to support river conservation and restoration/rehabilitation will depend on the generation of accurate relationships between natural, as well as altered flows, and ecological responses for rivers of different hydrology. There is a need to construct and calibrate ecological response relationships along gradients of hydrologic alteration for the biological communities of river ecosystems and for ecosystem processes (e.g., nutrient dynamics, energy flow, food web structure) in contrasting hydro-climatic settings across the globe. We have included 
new methods and protocols that address this challenge (Acreman \& Ferguson, this volume; Kennard et al., this volume; Poff et al., this volume; Poff \& Zimmerman, this volume; Shafroth et al., this volume).

(2) Flow-related guilds. Whilst species responses are informative, the identification of guilds with known responses to hydrologic alterations associated with specific stream types and hydro-climatic regions would be a major advance. Quantifying attributes of species and defining the flow-related guilds to which they belong is critical (Dunbar et $a l$. , this volume; Merritt et al., this volume). Ideally, such studies would lead to catalogues of flow-related guilds for plants, invertebrates and fish, as well as associated sets of fundamental guiding principles and flow-ecology relationships for different ecosystem components, flow regime characteristics or modifications, and hydrological river classes.

(3) Temperature and other 'drivers'. Driving variables acting on river systems (temperature, sediment, organic matter and more general water quality) are dynamic and potentially amenable to management intervention by manipulating river flows and through sustainable practices of catchment management. These drivers do not necessarily follow from water flow alone but are influenced by, and influence, water flowing over land, in rivers and in groundwater (Olden \& Naiman, this volume; Shafroth et al., this volume; Stewart-Koster et al., this volume). Understanding interactions among these regimes, and identifying response thresholds in different hydro-climatic settings, will be especially important to achieve integrated catchment/ basin management.

(4) Bayesian decision networks and Bayesian statistical models. Before-after studies of flow alteration impacts applying conventional statistical designs and analytical techniques play an important part in environmental flow studies and evaluation of their outcomes (King et al., this volume). However, there are likely to be design limitations in many riverine landscapes that demand different approaches. Where other methods are likely to violate statistical principles, Bayesian decision networks and statistical models may offer flexibility and innovation, and their use is gaining momentum (Arthington et 
al., 2007; Stewart-Koster et al., this volume; Webb et al., this volume). We recommend a more thorough exploration of these and other statistical methods and models of potential utility in hydro-ecological studies.

(5) Adaptive environmental management. Uncertainties in the ecological responses to flow regime change must be addressed in ways that convince managers and the public of the ecological and societal benefits of environmental flow allocations. An adaptive management perspective, linked to an empirical validation process for fine-tuning of environmental flow models and management targets, seems essential (Poff et al., 2003; King et al., this volume; Shafroth et al., this volume). Organisational and operational flexibility are important to facilitate discussions among scientists and managers and to continuously evaluate the risks and benefits of managed flow events.

(6) Ecological and societal goods, services and trade-offs. Quantifying ecological goods and services provided by rivers, and establishing better links between environmental flows and organism health, as well as cultural and ecological sustainability, are important priorities for research (Millennium Ecosystem Assessment, 2005; Palmer \& Filoso, 2009). We emphasize the need to advance the social side of environmental flows to ensure effective participation and application at appropriate scales in all socio-economic contexts. How does one educate the public to fully appreciate the importance of the natural rhythm of rivers? Further, establishing environmental flows often means giving up other perceived benefits derived from the use of river water. How does a society approach this age-old issue in a rational way? King \& Brown (this volume) offer a way forward in their discussion of the concept of 'Development Space'.

(7) Integrated Water Resource Management. In many countries there is general acceptance that the concept of water for the environment should be extended to groundwater-dependent ecosystems, estuaries and even near-shore areas. A further challenge is to incorporate land use activities that intercept or exacerbate overland flows into a whole of water cycle approach. Environmental flow assessments should merge seamlessly into Integrated Water Resource Management - 'a process that promotes the coordinated development and management of 
water, land and related resources, in order to maximize the resultant economic and social welfare in an equitable manner without compromising the sustainability of vital ecosystems' (Global Water Partnership, 2000; Hirji \& Davis 2009). Finding acceptable ways for multiple use of rivers, such as combining the generation of hydroelectricity with maintenance of ecological functions by means of environmental flows, represents a major challenge (International Hydropower Association, 2004; Renöfält et al., this volume). Climate change intensifies the urgency (Palmer et al., 2008).

Climate change. Development of adaptive environmental flow management in response to opportunities and constraints offered by climate-change driven alterations in river flow is a priority. For example, seasonal regime shifts may present situations where water management measures involving relatively small losses of hydropower (Renöfält et $a l$., this volume) or agricultural production can have major ecological advantages. Sound environmental flow management hedges against potentially serious and irreversible damage to freshwater ecosystems from climate change impacts by maintaining and enhancing ecosystem resiliency (Bond et al., 2008).

(9) Capacity-building. A key challenge is to educate a new generation of water scientists and policy makers well acquainted with environmental-flow concepts and practice, who can work in all biogeographical settings and cultures. The most workable approach would be to promote the training programmes of groups such as TNC, WWF, IUCN, UNESCO-IHE, the World Bank and the International Water Centre (Australia), and, at the same time, establish pilot implementation schemes in different regions to demonstrate the practicability of the environmental flows process.

To conclude, we hope that the papers presented in this Special Issue, and our recommendations above, will contribute to an invigorated research effort focused on hydro-ecological processes and river protection/restoration across a variety of hydroclimatic regions, cultures and economies. We anticipate that research embedded in environmental flow implementation and capacity-building projects will help to alleviate the trend toward further losses of biodiversity, and associated social and economic 
consequences. Such a programme should harness and reinforce the many international, national, institutional and individual efforts already contributing to the protection of river ecosystems, and would help us to achieve the water-related Millennium Development Goals. We have set out the tools needed - now we must do the essential science and apply the outcomes - or risk further drastic losses of freshwater biodiversity as well as ecological and cultural services of profound importance to humanity.

\section{Acknowledgements}

The Guest Editors thank Professor David Strayer for his vital editorial role, continued guidance and support during the preparation of this Special Issue of Freshwater Biology, and Professors Mark Gessner and Colin Townsend for their earlier contributions. We appreciate the work of many colleagues who provided timely and insightful reviews of papers, and we thank our respective institutions and funding agencies for support. Last but not least, we thank all the authors of papers for their efforts and patience while the issue was being assembled. This Special Issue represents a collaborative contribution to the science programmes of the DIVERSITAS Freshwater Cross-cutting Network and the Global Water System Project (GWSP).

\section{References}

Acreman M.C. \& Dunbar M.J. (2004) Defining environmental flow requirements: a review. Hydrology and Earth System Sciences, 8, 861-876.

Acreman M.C. \& Ferguson A.J.D. (2009) Environmental flows and the European Water Framework Directive. Freshwater Biology, (this volume).

Alcamo J., Vörösmarty C. Naiman R.J., Lettenmaier D., \& Pahl-Wostl C. (2008) A grand challenge for freshwater research: understanding the global water system. Environmental Research Letters, 3, 1-6.

Allan J.D. (2004) Landscapes and riverscapes: the influence of land use on stream ecosystems. Annual Review of Ecology, Evolution and Systematics, 35, 257-284. 
Arthington A., Baran E., Brown C.A., Dugan P., Halls A.S., King J.M., Minte-Vera C.V., Tharme R.E. \& Welcomme R.L. (2007) Water requirements of floodplain rivers and fisheries: existing decision support tools and pathways for development. Comprehensive Assessment of Water Management in Agriculture, Research Report 17, International Water Management Institute. Colombo, Sri Lanka. (URL: http://www.iwmi.cgiar.org/assessment/files_new/publications/CA\%20Research\% 20Reports/CARR17.pdf)

Arthington A.H., Bunn S.E., Poff N.L. \& Naiman R.J. (2006) The challenge of providing environmental flow rules to sustain river ecosystems. Ecological Applications, 16, 1311-1318.

Arthington A.H. \& Pusey B.J. (2003) Flow restoration and protection in Australian rivers. River Research and Applications, 19, 377-395.

Arthington A.H., Rall J.L., Kennard M.J. \& Pusey B.J. (2003) Environmental flow requirements of fish in Lesotho Rivers using the DRIFT methodology. River Research and Applications, 19, 641-666.

Arthington A.H., Tharme R. Brizga S.O., Pusey B.J. \& Kennard M.J. (2004).

Environmental flow assessment with emphasis on holistic methodologies. In: Proceedings of the Second International Symposium on the Management of Large Rivers for Fisheries Volume II (Eds R. Welcomme \& T. Petr), pp. 37-65. RAP Publication 2004/17, FAO Regional Office for Asia and the Pacific, Bangkok, Thailand.

Baron J.S., Poff N.L., Angermeier P.L., Dahm C.N., Gleick P.H., Hairston N.G., Jackson R.B., Johnston C.A., Richter B.D. \& Steinman A.D. (2002) Meeting ecological and societal needs for freshwater. Ecological Applications, 12, 1247-1260.

Bernhardt E.S., Bunn S.E., Hart D.D., Malmqvist B., Muotka T., Naiman R.J., Pringle C., Reuss M. \& van Wilgen B.W. (2006) The challenge of ecologically sustainable water management. Water Policy, 8, 475-479.

Bernhardt E. S., Palmer M.A., Allan J.D., Alexander G., Barnas K., Brooks S., Carr J., Clayton S., Dahm C., Follstad-Shah J., Galat D., Gloss S., Goodwin P., Hart D., Hassett B., Jenkinson R., Katz S., Kondolf G.M., Lake P.S., Lave R., Meyer J.L., 
O'Donnell T.K., Pagano L., Powell B. \& Sudduth E. (2005) Synthesizing U.S. river restoration efforts. Science, $\mathbf{3 0 8}$, 636-637.

Biggs H.C. \& Rogers K.H. (2003) An adaptive system to link science, monitoring, and management in practice. In: The Kruger Experience. Ecology and Management of Savanna Heterogeneity (Eds J.T. du Toit, K.H. Rogers \& H.C. Biggs), pp: 59-80. Island Press, Washington, DC.

Bond N.R., Lake P.S. \& Arthington A.H. (2008) The impacts of drought on freshwater ecosystems: an Australian perspective. Hydrobiologia, 600, 3-16.

Bovee K.D., Lamb B.L., Bartholow J.M., Stalnaker C.B., Taylor J. \& Henriksen J. (1998) Stream habitat analysis using the instream flow incremental methodology. U.S. Geological Survey, Information and Technology Report, USGS/BRD-1998-0004.

Brisbane Declaration (2007) The Brisbane Declaration. Environmental Flows are Essential for Freshwater Ecosystem Health and Human Well-Being. Declaration of the $10^{\text {th }}$ International Riversymposium and International Environmental Flows Conference, Brisbane, Australia, 3-6 September 2007.

Bunn S.E. \& Arthington A.H. (2002) Basic principles and ecological consequences of altered flow regimes for aquatic biodiversity. Environmental Management, 30, 492-507.

Bunn S.E., Davies P.M., \& Mosisch T.D. (1999) Ecosystem measures of river health and their response to riparian and catchment degradation. Freshwater Biology, 41, $333-345$.

COAG (2004) Intergovernmental agreement on addressing water over allocation and achieving environmental objectives in the Murray-Darling Basin. Council of Australian Governments. Department of the Prime Minister and Cabinet, Canberra. (URL: http://www.coag.gov.au/meetings/250604/index.htm\#nwi)

Cottingham P., Thoms M.C. \& Quinn G.P. (2002) Scientific panels and their use in environmental flow assessment in Australia. Australian Journal of Water Resources, 5, 103-111.

Downes B.J., Barmuta L.A., Fairweather P.G., Faith D.P., Keough M.J., Lake P.S., Mapstone B.D. \& Quinn G.P. (2002) Monitoring Ecological Impacts. Concepts 
and Practice in Flowing Waters. Cambridge University Press, Cambridge, United Kingdom.

Dudgeon D., Arthington A.H., Gessner M.O., Kawabata Z.I., Knowler D.J., Lévêque C., Naiman R.J., Prieur-Richard A.H., Soto D., Stiassny M.L.J. \& Sullivan C.A. (2006) Freshwater biodiversity: importance, threats, status and conservation challenges. Biological Reviews, 81, 163-182.

Dunbar M.J., Pedersen M.L., Cadman D., Extence C., Waddingham J., Chadd R. \& Larsen S.E (2009) River discharge and local-scale physical habitat influence macroinvertebrate LIFE score. Freshwater Biology, (this volume).

Dynesius, M. \& Nilsson, C. (1994) Fragmentation and flow regulation of river systems in the northern third of the world. Science 266, 753-762.

Dyson M., Bergkamp M. \& Scanlon J. (2003) Flow: The Essentials of Environmental Flows. IUCN, Gland, Switzerland and Cambridge, UK.

European Commission (2000) Directive 2000/60/EC of the European Parliament and of the Council of 23 October 2000 Establishing a Framework for Community Action in the Field of Water Policy. Official Journal 22 December 2000 L 327/1. European Commission, Brussels.

Gladwell M. (2000) The Tipping Point: How Little Things Can Make a Big Difference. Little Brown and Company, Boston, MA.

Global Water Partnership (2000) Integrated water resource development. GWP Technical Advisory Committee Background Paper 4. GWP, Stockholm, March 2000.

Gippel C.J. \& Stewardson M.J. (1998) Use of wetted perimeter in defining minimum environmental flows. Regulated Rivers: Research \& Management, 14, 53-67.

GWSP (2005) Global Water System Project. Science framework and implementation activities. ESSP Report No. 3, Earth System Science Partnership. (URL: http://www.gwsp.org/products.html).

Hirji R. \& Davis R. (2009) Environmental Flows in Water Resources Policies, Plans, and Projects: Findings and Recommendations. The World Bank, Washington, DC. 
International Hydropower Association (2004) Sustainability Guidelines. International Hydropower Association, Sutton, UK.

IWMI (International Water Management Institute) (2006) Insights from the Comprehensive Assessment of Water Management in Agriculture. Report of the International Water Management Institute, Colombo, Sri Lanka.

Jansson R., Nilsson C. \& Malmqvist B. (2007) Restoring freshwater ecosystems in riverine landscapes: the roles of connectivity and recovery processes. Freshwater Biology, 32, 589-596.

Junk W.J., Bayley P.B. \& Sparks R.E. (1989) The flood pulse concept in river-floodplain systems. Canadian Special Publication of Fisheries and Aquatic Sciences, 106, 110-127.

Kennard M. J., Olden J.D., Arthington A.H., Pusey B.J. \& Poff N.L. (2007) Multiscale effects of flow regime and habitat and their interaction on fish assemblage structure in eastern Australia. Canadian Journal of Fisheries and Aquatic Sciences, 64, 1346-1359.

Kennard M.J., Pusey B.J., Olden J.D., Mackay S.J., Stein J.L. \& Marsh N. (2009) Ecohydrological classification of natural flow regimes to support environmental flow assessments: an Australian case study. Freshwater Biology, (this volume).

King A.J., Ward K. A., O’Connor P. \& Green D. (2009) Adaptive management of an environmental watering event to enhance native fish spawning and recruitment. Freshwater Biology, (this volume).

King J. \& Brown C. (2006) Environmental flows: striking the balance between development and resource protection. Ecology and Society, 11 (2), 26 [online] URL: http://www.ecologyandsociety.org/vol11/iss2/art26/

King J. M. \& Brown C. (2009) Integrated Basin Flow Assessments: concepts and method development in Africa and South-east Asia. Freshwater Biology, (this volume).

King J., Brown C. \& Sabet H. (2003) A scenario-based holistic approach to environmental flow assessments for rivers. River Research and Applications, 19, 619-639. 
Lake P.S., Bond N. \& Reich P. (2007) Linking ecological theory with stream restoration. Freshwater Biology 52, 597-615.

Lytle D.A. \& Poff N.L. (2004) Adaptation to natural flow regimes. Trends in Ecology and Evolution, 19, 94-100.

Malmqvist B. \& Rundle S. (2002) Threats to the running water ecosystems of the world. Environmental Conservation, 29, 134-153.

Merrett S. (2007) The Thames catchment: a river basin at the tipping point. Water Policy, 9, 393-404.

Merritt D.M., Scott M.L., Poff N.L. \& Lytle D.A. (2009) Theory, methods, and tools for determining environmental flows for riparian vegetation: riparian vegetation-flow response guilds. Freshwater Biology, (this volume).

Millennium Ecosystem Assessment (2005) Millennium Ecosystem Assessment Synthesis Report. Island Press, Washington DC.

Milly P.C.D., Betancourt J., Falkenmark M., Hirsch R.M., Kundzewicz Z.W., Lettenmaier D.P. \& Stouffer R.J. (2008) Stationarity is dead: whither water management? Science, 319, 573-574.

Merritt D.M., Scott M.L., Poff N.L. \& Lytle D.A. (2009) Theory, methods, and tools for determining environmental flows for riparian vegetation: riparian vegetation-flow response guilds. Freshwater Biology, (this volume).

Alcamo J., Vörösmarty C. Naiman R.J., Lettenmaier D., \& Pahl-Wostl C. (2008) A grand challenge for freshwater research: understanding the global water system. Environmental Research Letters, 3, 1-6.

Bovee K.D., Lamb B.L., Bartholow J.M., Stalnaker C.B., Taylor J. \& Henriksen J. (1998) Stream habitat analysis using the instream flow incremental methodology. U.S. Geological Survey, Information and Technology Report, USGS/BRD-1998-0004.

Hirji R. \& Davis R. (2009) Environmental Flows in Water Resources Policies, Plans, and Projects: Findings and Recommendations. The World Bank, Washington, DC. 
Lytle D.A. \& Poff N.L. (2004) Adaptation to natural flow regimes. Trends in Ecology and Evolution, 19, 94-100.

Millennium Ecosystem Assessment (2005) Millennium Ecosystem Assessment Synthesis Report. Island Press, Washington DC.

Naiman R.J., Bunn S.E., Nilsson C., Petts G.E., Pinay G. \& Thompson L.C. (2002) Legitimizing fluvial ecosystems as users of water: an overview. Environmental Management, 30, 455-467.

Naiman R.J. \& Dudgeon D. (in press) Global alteration of freshwaters: influences on human and environmental well-being. Ecological Research.

Naiman R.J., Latterell J.J., Pettit N.E. \& Olden J.D. (2008) Flow variability and the biophysical vitality of river systems. Comptes Rendus Geosciences, 340, 629-643.

Naiman R.J., Prieur-Richard A-H. Arthington A.H., Dudgeon D. Gessner M.O. Kawabata Z., Knowler D., O'Keeffe J., Lévêque C., Soto D., Stiassny M. \& Sullivan C. (2006) freshwaterBIODIVERSITY: Challenges for Freshwater Biodiversity Research. DIVERSITAS Report No. 5, Paris, France. 48 pages. (URL: http://www.diversitasinternational.org/docs/diversitas/freshwaterBI)

Nilsson C., Jansson R., Malmqvist B. \& Naiman R.J. (2007) Restoring riverine landscapes: The challenge of identifying priorities, reference states, and techniques. Ecology \& Society, 12 (1), 16 [online) URL: http://www.ecologyandsociety.org/vol12/iss1/art16/

Nilsson C., Reidy C.A., Dynesius M. \& Revenga C. (2005) Fragmentation and flow regulation of the world's large river systems. Science, 308, 405-408.

Nilsson C. \& Renöfält B.M. (2008) Linking flow regime and water quality in rivers: a challenge to adaptive catchment management. Ecology \& Society, 13(2), 18 [online] URL: http://www.ecologyandsociety.org/vol13/iss2/art18/

Nilsson C. \& Svedmark M. (2002) Basic principles and ecological consequences of changing water regimes: riparian plant communities. Environmental Management, 30, 468-480. 
Olden J.D. \& Naiman R.J. (2009) Broadening the science of environmental flows: managing riverine thermal regimes for ecosystem integrity. Freshwater Biology, (this volume).

Palmer M.A., Bernhardt E.S., Allan J.D., Lake P.S., Alexander G., Brooks S., Carr J., Claytong S., Dahm C.N., Follstad Shah J., Galat D.L., Gloss S., Goodwin P., Hart D.D., Hassett B., Jenkinson R., Kondolf G.M., Lave R., Meyer J.L., O’Donnell T.K., Pagano L. \& Sudduth E. (2005) Standards for ecologically successful river restoration. Journal of Applied Ecology, 42, 208-217.

Palmer M.A. \& Filoso, S. (2009) Restoration of ecosystem services for environmental markets. Science 325, 575-576.

Palmer M.A., Reidy Liermann C.A., Nilsson C., Flörke M., Alcamo J., Lake P.S. \& Bond N. (2008) Climate change and the world's river basins: anticipating management options. Frontiers in Ecology and the Environment, 6, 81-89.

Pearce F. (2007) When the Rivers Run Dry: What Happens When our Water Runs Out? Transworld Publishers, London.

Pinay G., Clément J.C. \& Naiman R.J. (2002) Basic principles and ecological consequences of changing water regimes on nitrogen cycling in fluvial system. Environmental Management 30, 481-491.

Poff N.L. \& Allan J.D. (1995) Functional organization of stream fish assemblages in relation to hydrologic variability. Ecology, 76, 606-627.

Poff N.L., Allan J.D., Bain M.B., Karr J.R., Prestegaard K.L., Richter B.D., Sparks R.E. \& Stromberg J.C. (1997) The natural flow regime: a paradigm for river conservation and restoration. BioScience, 47, 769-784.

Poff N.L., Allan J.D., Palmer M.A., Hart D.D., Richter B.D., Arthington A.H., Rogers K.H., Meyer J.L. \& Stanford J.A. (2003) River flows and water wars: emerging science for environmental decision making. Frontiers in Ecology and the Environment, 1, 298-306.

Poff N.L., Olden J.D., Vieira N.K.M., Finn D.S., Simmons M.P. \& Kondratieff B.C. (2006) Functional trait niches of North American lotic insects: trait-based 
ecological applications in light of phylogenetic relationships. Journal of the North American Benthological Society, 25, 730-755.

Poff N.L., Richter B., Arthington A.H., Bunn S.E., Naiman, R.J. Kendy E., Acreman M., Apse C., Bledsoe B.P., Freeman M., Henriksen J., Jacobson R.B., Kennen J., Merritt D., O’Keefe J., Olden J.D., Rogers K., Tharme R. \& Warner A.T. (2009) The ecological limits of hydrologic alteration (ELOHA): a new framework for developing regional environmental flow standards. Freshwater Biology, (this volume).

Poff N.L. \& Zimmerman J.K. (2009) Ecological impacts of altered flow regimes: a metaanalysis to inform environmental flow management. Freshwater Biology, (this volume).

Postel S. (2005) Liquid assets: the critical need to safeguard freshwater ecosystems. Worldwatch Paper 170, Worldwatch Institute, Washington, DC.

Postel S. \& Carpenter S. (1997) Freshwater ecosystem services. In: Nature's Services: Societal Dependence on Natural Ecosystems (Ed. G.C. Daily). Island Press, Washington, DC.

Postel S. \& Richter B. (2003) Rivers for Life: Managing Water for People and Nature. Island Press, Washington, DC.

Power M.E., Sun A., Parker G., Dietrich W.E. \& Wootton J.T. (1995) Hydraulic foodchain models. BioScience, 45, 159-167.

Pusey B.J. \& Arthington A.H. (2003) Importance of the riparian zone to the conservation and management of freshwater fish: a review. Marine and Freshwater Research, 54, 1-16.

Renöfält B.M., Jansson R. \& Nilsson C. (2009) Effects of hydropower generation and opportunities for environmental flow management in Swedish riverine ecosystems. Freshwater Biology, (this volume).

Revenga C., Campbell I., Abell R., De Villiers P. \& Bryer M. (2005) Prospects for monitoring freshwater ecosystems towards the 2010 targets. Philosophical Transactions of the Royal Society B, 360, 397-413. 
Richter B.D. \& Thomas G.A. (2007) Restoring environmental flows by modifying dam operations. Ecology \& Society, 12 (1), 12 [online] URL:http://www.ecologyandsociety.org/vol12/iss1/art12/

Richter B.D., Warner A.T., Meyer J.L. \& Lutz K. (2006) A collaborative and adaptive process for developing environmental flow recommendations. River Research and Applications, 22, 297-318.

Sala O.E., Meyerson L.A. \& Parmesan C. (Eds) (2008) Biodiversity Change and Human Health. Island Press, Washington, DC.

Schreiber E.S.G., Bearlin A.R., Nicol A.R. \& Todd C.R. (2004) Adaptive management: a synthesis of current understanding and effective application. Ecological Management and Restoration, 5, 177-182.

Shafroth P.B., Andersen D.C., Beauchamp V.B., Hautzinger A., Hickey J.T., Lytle D., McMullen L., Warner A. \& Wilcox A. (2009) Models and tools to assist environmental flow assessment and implementation below reservoirs: lessons from an arid-region river. Freshwater Biology, (this volume).

Stanford J.A., Ward J.V., Liss W.J., Frissell C.A., Williams R.N., Lichatowich J.A. \& Coutant C.C. (1996) A general protocol for restoration of regulated rivers. Regulated Rivers: Research and Management, 12, 391-413.

Stewart-Koster B., Bunn S.E., Mackay S.J., Poff N.L., Naiman R.J. \& Lake P.S. (2009) The use of Bayesian networks to guide investments in flow and catchment restoration for impaired river ecosystems. Freshwater Biology, (this volume)

Stoddard J.L., Larsen D.P., Hawkins C.P., Johnson R.K. \& Norris R.H. (2006) Setting expectations for the ecological condition of streams: the concept of reference condition. Ecological Applications, 16, 1267-1276.

Tharme R.E. (2003) A global perspective on environmental flow assessment: emerging trends in the development and application of environmental flow methodologies for rivers. River Research and Applications, 19, 397-441.

TISORL (2007) Global change and river-floodplain ecosystems. $3^{\text {rd }}$ International Symposium on Riverine Landscapes, August 27 - September 1, 2007, South 
Stradbroke Island, Queensland, Australia. (URL:

http://www.griffith.edu.au/conference/tisorl2007/)

Tockner K., Bunn S., Gordon C., Naiman R.J., Quinn G.P. \& Stanford J.A. (2008) Flood plains:

critically threatened ecosystems. In: Aquatic Ecosystems (Ed. N.V.C. Polunin), pp. 45-

61. Cambridge University Press, Cambridge, UK.

Vörösmarty C.J., Green P., Salisbury J. \& Lammers R. (2000) Global water resources:

vulnerability from climate change and population growth. Science, 289, 284-288.

Vörösmarty C., Lettenmaier D., Lévêque C., Meybeck M., Pahl-Wostl C., Alcamo J., Cosgrove W., Grassl H., Hoff H., Kabat P., Lansigan E., Lawford R., \& Naiman R.J. (2004) Humans transforming the global water system. EOS, American Geophysical Union Transactions, 85, 509-514.

Walker K.F., Sheldon F. \& Puckridge J.T. (1995) An ecological perspective on dryland river ecosystems. Regulated Rivers: Research and Management, 11, 85-104.

Webb A.J, Stewardson M.J \& Koster W.M. (2009) Detecting ecological responses to flow variation using Bayesian hierarchical models. Freshwater Biology, (this volume).

Welcomme R.L., Bene C., Brown C.A., Arthington A.H., Dugan P., King J.M. \& Sugunan V. (2006) Predicting the water requirements of river fisheries. In: Wetlands and Natural Resource Management. Ecological Studies, Vol 90. (Eds. J.T.A. Verhoeven \& B. Beltman \& R. Bobbink \& D.F. Whigham), pp. 123-154. Springer-Verlag, Berlin.

Welcomme R.L., Winemiller K.O. \& Cowx I.G. (2006b) Fish environmental guilds as a tool for assessment of ecological condition of rivers. River Research and Applications, 22, 377-396.

World Commission on Dams (2000) Dams and Development a New Framework for Decision-making. The Report of the Word Commission on Dams. Earthscan Publications, London. 


\section{The Brisbane Declaration (2007)}

Environmental Flows ${ }^{I}$ are Essential for Freshwater Ecosystem Health and Human WellBeing

This declaration presents summary findings and a global action agenda that address the urgent need to protect rivers globally, as proclaimed at the $10^{\text {th }}$ International Riversymposium and International Environmental Flows Conference, held in Brisbane, Australia, on 3-6 September 2007. The conference was attended by more than 750 scientists, economists, engineers, resource managers and policy makers from more than 50 countries.

\section{Key findings include:}

Freshwater ecosystems are the foundation of our social, cultural, and economic wellbeing. Healthy freshwater ecosystems - rivers, lakes, floodplains, wetlands, and estuaries - provide clean water, food, fiber, energy and many other benefits that support economies and livelihoods around the world. They are essential to human health and well-being. Freshwater ecosystems are seriously impaired and continue to degrade at alarming rates. Aquatic species are declining more rapidly than terrestrial and marine species. As freshwater ecosystems degrade, human communities lose important social, cultural, and economic benefits; estuaries lose productivity; invasive plants and animals flourish; and the natural resilience of rivers, lakes, wetlands, and estuaries weakens. The severe cumulative impact is global in scope.

Water flowing to the sea is not wasted. Fresh water that flows into the ocean nourishes estuaries, which provide abundant food supplies, buffer infrastructure against storms and tidal surges, and dilute and evacuate pollutants.

Flow alteration imperils freshwater and estuarine ecosystems. These ecosystems have evolved with, and depend upon, naturally variable flows of high-quality fresh water. Greater attention to environmental flow needs must be exercised when attempting to manage floods; supply water to cities, farms, and industries; generate power; and facilitate navigation, recreation, and drainage. 
Environmental flow management provides the water flows needed to sustain freshwater and estuarine ecosystems in coexistence with agriculture, industry, and cities. The goal of environmental flow management is to restore and maintain the socially valued benefits of healthy, resilient freshwater ecosystems through participatory decision making informed by sound science. Ground-water and floodplain management are integral to environmental flow management.

Climate change intensifies the urgency. Sound environmental flow management hedges against potentially serious and irreversible damage to freshwater ecosystems from climate change impacts by maintaining and enhancing ecosystem resiliency.

Progress has been made, but much more attention is needed. Several governments have instituted innovative water policies that explicitly recognize environmental flow needs. Environmental flow needs are increasingly being considered in water infrastructure development and are being maintained or restored through releases of water from dams, limitations on ground-water and surface-water diversions, and management of land-use practices. Even so, the progress made to date falls far short of the global effort needed to sustain healthy freshwater ecosystems and the economies, livelihoods, and human well-being that depend upon them.

${ }^{1}$ Environmental flows describe the quantity, timing, and quality of water flows required to sustain freshwater and estuarine ecosystems and the human livelihoods and well-being that depend on these ecosystems. 


\section{Global Action Agenda}

The delegates to the $10^{\text {th }}$ International Riversymposium and Environmental Flows

Conference call upon all governments, development banks, donors, river basin organizations, water and energy associations, multilateral and bilateral institutions, community-based organizations, research institutions, and the private sector across the globe to commit to the following actions for restoring and maintaining environmental flows:

1. Estimate environmental flow needs everywhere immediately. Environmental flow needs are currently unknown for the vast majority of freshwater and estuarine ecosystems. Scientifically credible methodologies quantify the variable - not just minimum - flows needed for each water body by explicitly linking environmental flows to specific ecological functions and social values. Recent advances enable rapid, regionwide, scientifically credible environmental flow assessments.

\section{Integrate environmental flow management into every aspect of land and water} management. Environmental flow assessment and management should be a basic requirement of Integrated Water Resource Management (IWRM); environmental impact assessment (EIA); strategic environmental assessment (SEA); infrastructure and industrial development and certification; and land-use, water-use, and energy-production strategies.

3. Establish institutional frameworks. Consistent integration of environmental flows into land and water management requires laws, regulations, policies and programs that: (1) recognize environmental flows as integral to sustainable water management, (2) establish precautionary limits on allowable depletions and alterations of natural flow, (3) treat ground water and surface water as a single hydrologic resource, and (4) maintain environmental flows across political boundaries.

4. Integrate water quality management. Minimizing and treating wastewater reduces the need to maintain un-naturally high streamflow for dilution purposes. Properly-treated wastewater discharges can be an important source of water for meeting environmental flow needs. 
5. Actively engage all stakeholders. Effective environmental flow management involves all potentially affected parties and relevant stakeholders and considers the full range of human needs and values tied to freshwater ecosystems. Stakeholders suffering losses of ecosystem service benefits should be identified and properly compensated in development schemes.

6. Implement and enforce environmental flow standards. Expressly limit the depletion and alteration of natural water flows according to physical and legal availability, and accounting for environmental flow needs. Where these needs are uncertain, apply the precautionary principle and base flow standards on best available knowledge. Where flows are already highly altered, utilize management strategies, including water trading, conservation, floodplain restoration, and dam re-operation, to restore environmental flows to appropriate levels.

\section{Identify and conserve a global network of free-flowing rivers. Dams and dry} reaches of rivers prevent fish migration and sediment transport, physically limiting the benefits of environmental flows. Protecting high-value river systems from development ensures that environmental flows and hydrological connectivity are maintained from river headwaters to mouths. It is far less costly and more effective to protect ecosystems from degradation than to restore them.

8. Build capacity. Train experts to scientifically assess environmental flow needs. Empower local communities to participate effectively in water management and policymaking. Improve engineering expertise to incorporate environmental flow management in sustainable water supply, flood management, and hydropower generation.

9. Learn by doing. Routinely monitor relationships between flow alteration and ecological response before and during environmental flow management, and refine flow provisions accordingly. Present results to all stakeholders and to the global community of environmental flow practitioners. 